\author{
Marek MADAJEWSKI ${ }^{1}$ \\ Zbigniew NOWAKOWSKI ${ }^{2}$ \\ Natalia ZNOJKIEWICZ ${ }^{3}$
}

\title{
ANALIZA MES WPEYWU ZUŻYCIA POWIERZCHNI PRZYŁOŻENIA NARZĘDZIA NA JEGO OBCIĄŻENIE W SKRAWANIU ORTOGONALNYM STALI 42CrMo4
}

\begin{abstract}
W artykule przedstawiono analizę wpływu zużycia powierzchni przyłożenia (wskaźnik $V B_{B}$ ) na składowe siły całkowitej oraz rozkład nacisków na ostrzu podczas toczenia ortogonalnego. Dane eksperymentalne uzyskano, mierząc składowe siły całkowitej siłomierzem tensometrycznym oraz przez rejestrację wartości reakcji ostrza w modelu MES procesu formowania wióra. Badania eksperymentalne posłużyły do walidacji modeli numerycznych przygotowanych $\mathrm{w}$ programie ABAQUS. Określone pasmo zużycia zostało zamodelowane geometrycznie na powierzchni przyłożenia, a wpływ tego zużycia został oceniony w niezależnych symulacjach. Model numeryczny formowania wióra wykorzystuje równanie konstytutywne Johnsona-Cooka do opisu wartości i rozkładu naprężeń w przedmiocie obrabianym, a ostrze z zamodelowanym zużyciem zostało opisane jako ciało idealnie sztywne. Mechanikę procesu skrawania przedstawiono, odwołując się do modelu Merchanta skrawania ortogonalnego, nanosząc wykreślnie wektory przyrostu składowych siły całkowitej obliczone MES na tle zamodelowanego konturu strefy skrawania. Wyniki pomiarów i symulacji wskazują, że wzrost zużycia określony wskaźnikiem $V B_{B}$ wpływa bezpośrednio na wzrost składowych siły całkowitej.
\end{abstract}

Słowa kluczowe: metoda elementów skończonych, zużycie narzędzia, modelowanie, rozkład nacisków, składowe siły całkowitej

\section{Wprowadzenie}

Przed rozwinięciem technik numerycznych, takich jak metoda elementów skończonych (MES), badacze wykorzystywali narzędzia analityczne, w tym tradycyjny model Merchanta czy Oxleya do oceny rozkładu sił w warstwie wióra. Później zaproponowano $[5,8]$ wprowadzenie zmian do modelu Merchanta w celu

\footnotetext{
1 Autor do korespondencji/corresponding author: Politechnika Poznańska, ul. Piotrowo 3, 60-965 Poznań, tel.: 616652723, e-mail: marek.w.madajewski@doctorate.put.poznan.pl

2 Zbigniew Nowakowski, Politechnika Poznańska, e-mail: zbigniew.nowakowski@put.poznan.pl

${ }^{3}$ Natalia Znojkiewicz, Politechnika Poznańska, e-mail: natalia.w.znojkiewicz@doctorate.put. poznan.pl
} 
ujęcia wpływu zużycia ostrza na składowe siły całkowitej. Z kolei pierwsze próby wykorzystania metody elementów skończonych do analizy procesu formowania wióra pojawiły się już w latach 80 . i były regularnie udoskonalane. W modelowaniu MES są zauważalne dwa zasadnicze trendy: formowanie wióra wskutek zastosowania mechanizmu pękania $\mathrm{w}$ warstwie przejściowej $[1,3]$ lub formowanie wióra przez odkształcenia plastyczne warstwy materiału spowodowane zagłębianiem się klina $\mathrm{w}$ przedmiot obrabiany $[2,6]$. Ze względu na dysponowanie funkcjonującymi modelami procesu skrawania możliwe było skierowanie uwagi na miejsce zużycia w mechanice skrawania. W pracach Usui [7] zaproponowano wykorzystanie MES do estymowania zużycia na podstawie symulacji procesu skrawania. Zużycie powstawało przez przemieszczenie węzłów siatki na powierzchni ostrza na podstawie wartości temperatury i nacisków, jednak symulacje cechowały się olbrzymią czasochłonnością. Z tego powodu część badaczy [1,3], aby ocenić wpływ zużycia na fizykalne aspekty skrawania, zdecydowała o geometrycznym zamodelowaniu starcia na powierzchni przyłożenia w sposób dyskretny (każdy kolejny stan zużycia stanowi kolejną symulację). Umożliwiło to ograniczenie czasochłonności badań, gdyż liczba potrzebnych symulacji zmniejsza się z kilku tysięcy do zaledwie kilkunastu. Celem tej pracy jest określenie wpływu zużycia ostrza na wielkość składowych siły całkowitej oraz wskazanie przyczyny tego zjawiska przez odwołanie się do modeli analitycznych oraz rozkładów nacisków powierzchniowych na ostrzu uzyskanych na drodze obliczeń MES.

\section{Metodyka badań}

Model uwzględniający warunki płaskiego stanu odkształcenia (PSO) został przygotowany w module Explicit programu ABAQUS, który służy do rozwiązywania nieliniowych problemów z zakresu dynamiki przez zastosowanie jawnego całkowania równań ruchu. Na rysunku 1 przedstawiono dwuwymiarowy model MES formowania wióra w skrawaniu ortogonalnym. Rozwiązanie dostarczy rozkłady i wartości temperatury, naprężeń, nacisków w funkcji czasu. W dwuwymiarowej analizie skrawania ortogonalnego przedmiot obrabiany można zamodelować jako prostokąt, który pozwoli na analizę 1,2 ms procesu skrawania w zadanych warunkach skrawania. W zamodelowanej parze kinematycznej ruch wykonuje narzędzie, dlatego utwierdzono podstawę oraz lewy bok prostokąta reprezentującego przedmiot obrabiany, a dla powierzchni ostrza zadano warunki brzegowe typu prędkościowego, które zamiast utwierdzić grupę węzłów, wymuszają jej przemieszczenie z określoną przez użytkownika prędkością. Warunki brzegowe typu prędkościowego opisują prędkość przemieszczeń węzłów ostrza w kierunku X (kierunek ruchu głównego $v_{c}$ ) oraz Y (kierunek ruchu posuwowego $v_{f}$ ). W skrawaniu ortogonalnym grubość warstwy skrawanej jest równa wartości posuwu. Dla dwuwymiarowej analizy MES w PSO grubość brył musi być zdefiniowana, aby uwzględnić pojemność cieplną badanych ciał oraz prędkość 
przepływu temperatury. Jest to określane przez przypisanie grubości sekcji do konturów brył. Przedmiot obrabiany zdefiniowano z grubością sekcji $3 \mathrm{~mm}$ (odpowiadającą głębokości skrawania $a_{p}$ ), a ostrze ma przypisaną grubość $12 \mathrm{~mm}$ (grubość zastosowanej płytki). W przypadku niezdefiniowania grubości sekcji zagadnienie byłoby rozwiązywane dla głębokości skrawania równej $1 \mathrm{~m}$.

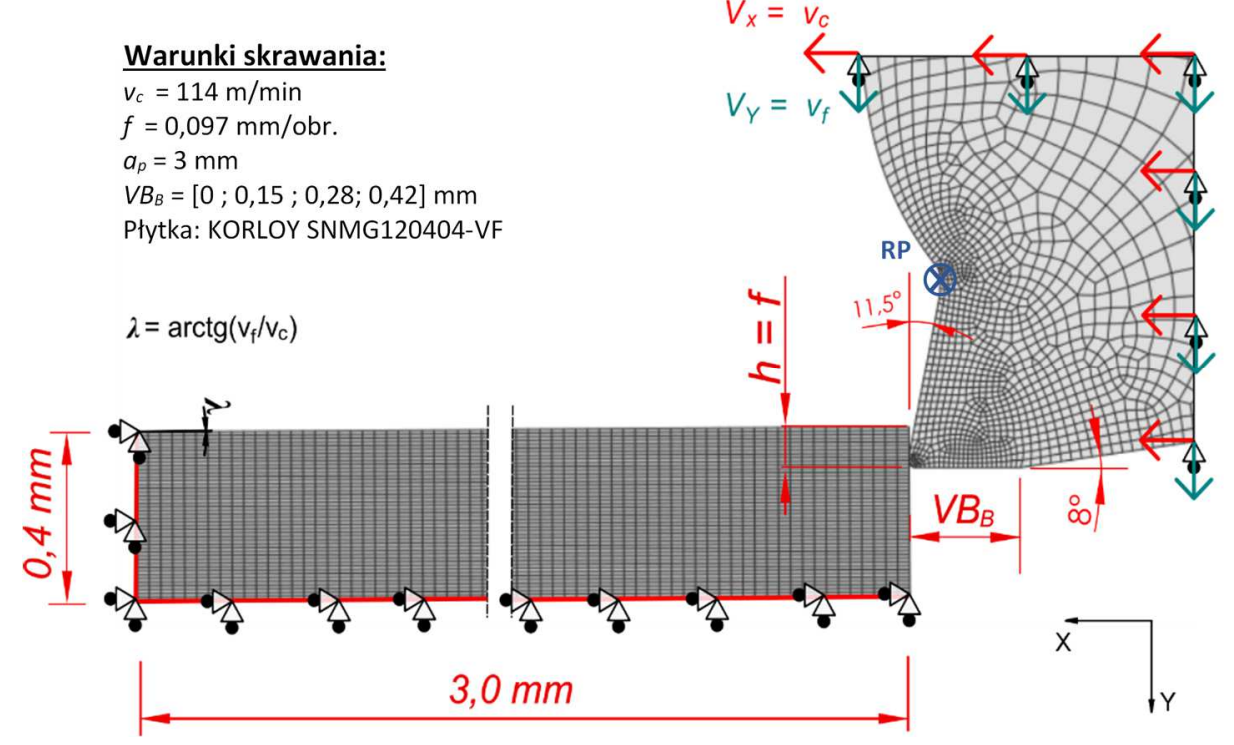

Rys. 1. Model MES formowania wióra uwzględniający zużycie powierzchni przyłożenia

Fig. 1. The FEM model of chip formation accounting flank wear

Na ostrze jest nałożony warunek ciała sztywnego (RIGID BODY), który definiuje stałe położenie wszystkich węzłów wchodzących w skład domeny materiału ostrza względem jednego arbitralnie wybranego punktu referencyjnego $(R P)$. Skutkiem tego będzie wyłączenie analizy związku naprężeniowo-odkształceniowego z domeny ostrza. Formowanie wióra jest spowodowane stopniowym zagłębianiem się klina ostrza w przedmiot obrabiany. W rezultacie jednostajnego ruchu ostrza zagłębianie się klina będzie zachodzić w modelu MES bez względu na ilość pracy potrzebnej do plastycznego odkształcenia przedmiotu obrabianego. Model MES nie wyznacza bezpośrednio wartości składowych siły całkowitej, lecz rejestruje reakcję ostrza na działanie nacisków na wszystkich jego powierzchniach. Reakcje w programie ABAQUS są rejestrowane w punkcie RP, który przejmuje obciążenie działające na całe ciało nieodkształcane. Reakcje są wyrażone przez zmienne RF1 oraz RF2 kolejno jako reakcja w kierunki $X$ (siła $F_{c}$ ) oraz w kierunku $Y\left(\right.$ siła $\left.F_{f}\right)$.

W przeciwieństwie do ostrza, materiał obrabiany zostanie poddany w czasie analizy znacznym odkształceniom, które spowodują zniekształcenie siatki elementów skończonych. W celu przeciwdziałania deformacji siatki zastosowano 
na przestrzeni materiału obrabianego sprzężony opis ruchu Lagrange'a-Eulera (ALE - Arbitrary Lagrangian-Eulerian). ALE jest ogólną adaptacyjną metodą formułowania rządzącą przemieszczeniem węzłów oraz materiału wewnątrz domeny zagadnienia. Łączy ona klasyczny opis Lagrange'a (przemieszczenia materiału oraz węzłów siatki są jednakowe) z opisem Eulera (materiał przemieszcza się na tle ustalonych w przestrzeni węzłów). Tutaj punkty węzłów siatki elementów skończonych nie są ani przytwierdzone do materiału, ani nie są na stałe umiejscowione w przestrzeni. Efektem stosowania opisu ALE jest wygładzanie siatki i utrzymanie topologii siatki zbliżonej do pierwotnej, gdyż jest ona ciągle przebudowywana, a wartości zmiennych węzłowych są interpolowane na do nowych położeń węzłów. Stąd opis ALE nadaje się do symulacji, w której występują znaczne odkształcenia, ale nie dopuszcza on możliwości usuwania elementów $\mathrm{z}$ domeny zagadnienia, przez co można analizować skrawanie w warunkach ciągłego wióra. Dla sprzężonej temperaturowo-przemieszczeniowej analizy w płaskim stanie odkształcenia w programie ABAQUS wybrano 4-węzłowy typ elementu CPE4RT. Obszar materiału obrabianego został podzielony na prostokątne elementy o jednakowej wielkości, których stosunek długości do wysokości wynosi 3:1. Taki stosunek boków prostokątnych elementów pozwala na realizację symulacji przy udziale ALE, gdyż algorytm utrzymuje przy nim topologię siatki zbliżoną do pierwotnej. W przypadku ostrza siatka została celowo zagęszczona w okolicy krawędzi skrawającej oraz pasma zużycia powierzchni przyłożenia, w celu dokładniejszego śledzenia rozkładów temperatur i nacisków.

Do opisu relacji naprężeniowo-odkształceniowej w materiale obrabianym, gdzie występują odkształcenia plastyczne o dużej intensywności, należy zastosować odpowiedni model konstytutywny. W latach 80. badacze Johnson i Cook zaproponowali model do analiz numerycznych służący do wyznaczenia wartości naprężenia zastępczego Hubera-Misesa, z uwzględnieniem wpływu prędkości odkształceń oraz temperatury. Model znalazł zastosowanie w analizach wytężenia w konstrukcjach poddanych nagłym uderzeniom oraz procesom formowania metali. Model jest wyrażony za pomocą wzoru $[1,6]$ :

$$
\sigma_{y}=\left(\mathrm{A}+\mathrm{B} \varepsilon_{p}^{\mathrm{n}}\right)\left(1+\mathrm{C} \ln \left(\frac{\dot{\varepsilon}_{p}}{\dot{\varepsilon}_{\mathrm{p}}^{0}}\right)\right)\left(1-\left(\frac{T-\mathrm{T}_{\mathrm{o}}}{\mathrm{T}_{\mathrm{t}}-\mathrm{T}_{\mathrm{o}}}\right)^{\mathrm{m}}\right)
$$

gdzie w równaniu (1) do zmiennych niezależnych należy $\varepsilon_{p}$ - zastępcze odkształcenie plastyczne, $\dot{\varepsilon}_{p}$ - zastępcza prędkość odkształcenia plastycznego oraz $T$ temperatura przedmiotu obrabianego. W dynamicznych symulacjach oprócz modelu konstytutywnego stosuje się model zniszczenia materiału Johnsona-Cooka. Zastosowanie modelu powoduje stopniową degradację sztywności przez element poddany znacznym deformacjom. Wzór wyznaczający zastępcze odkształcenie $\bar{\varepsilon}_{D}^{p l}$ podczas inicjacji uszkodzenia jest wyrażany za pomocą zależności $[1,6]$ : 


$$
\bar{\varepsilon}_{D}^{p l}=\left[D_{1}+D_{2} \exp \left(D_{3} \eta\right)\right]\left[1+D_{4} \ln \left(\frac{\dot{\varepsilon}_{p}}{\dot{\varepsilon}_{p}^{0}}\right)\right]\left[1-D_{5}\left(\frac{T-T_{o}}{T_{t}-T_{o}}\right)^{m}\right]
$$

w równaniu $D_{1}-D_{5}$ są parametrami inicjacji zniszczenia ustalanymi w próbie statycznego rozciągania i skręcania, a bezwymiarowa stała $\eta=\sigma_{m} / \bar{\sigma}$ określa stosunek średniego naprężenia $\sigma_{m} \mathrm{~W}$ trzech normalnych kierunkach do zastępczego naprężenia Hubera-Misesa $\bar{\sigma}$. Wszystkie parametry opisujące równanie konstytutywne oraz model zniszczenia dla stali $42 \mathrm{CrMo} 4$ zostały oparte na pracach [6] i zestawiono je w tab. 1 wraz z pozostałymi stałymi potrzebnymi do opisu zachowania materiału w sprzężonej termomechanicznej analizie MES.

Tabela 1. Parametry równania Johnsona-Cooka oraz stałe termomechaniczne

Table 1. Parameters of Johnson-Cook equation and thermal-mechanical constants

\begin{tabular}{|c|c|c|c|c|c|}
\hline \multicolumn{6}{|c|}{ Model Johnsona-Cooka dla stali 42CrMo4 } \\
\hline $\begin{array}{l}\text { Stała granicy plastyczno- } \\
\text { ści }\end{array}$ & $A[\mathrm{MPa}]$ & 595 & $\begin{array}{l}\text { Temperatura topnienia } \\
\text { materiału }\end{array}$ & $T_{t}[\mathrm{~K}]$ & 1793 \\
\hline Stała modułu utwardzania & $B[\mathrm{MPa}]$ & 580 & \multirow{5}{*}{$\begin{array}{l}\text { Parametry inicjacji znisz- } \\
\text { czenia }\end{array}$} & $D_{1}[-]$ & 1,5 \\
\hline $\begin{array}{l}\text { Współczynnik prędkości } \\
\text { odkształcania }\end{array}$ & $C[-]$ & 0,023 & & $D_{2}[-]$ & 3,44 \\
\hline Stała współ. utwardzania & $n[-]$ & 0,133 & & $D_{3}[-]$ & $-2,12$ \\
\hline $\begin{array}{l}\text { Stała zmiękczenia mate- } \\
\text { riału }\end{array}$ & $m[-]$ & 1,03 & & $D_{4}[-]$ & 0,002 \\
\hline $\begin{array}{l}\text { Ref. prędkość odkształce- } \\
\text { nia }\end{array}$ & $\dot{\bar{\varepsilon}}_{0}\left[\mathrm{~s}^{-1}\right]$ & 1000 & & $D_{5}[-]$ & 0,1 \\
\hline Temperatura odniesienia & $T_{o}[\mathrm{~K}]$ & 300 & & & \\
\hline Stałe termomechaniczne & & 42CrMo4 & \multicolumn{2}{|c|}{ Węglik } \\
\hline Gęstość & \multicolumn{2}{|c|}{$\rho\left[\mathrm{kg} / \mathrm{m}^{3}\right]$} & 7850 & \multicolumn{2}{|c|}{15000} \\
\hline Moduł Younga & \multicolumn{2}{|c|}{$E[\mathrm{GPa}]$} & 210 & \multicolumn{2}{|c|}{800} \\
\hline Współczynnik Poissona & \multicolumn{2}{|c|}{$v[-]$} & 0,3 & \multicolumn{2}{|c|}{0,2} \\
\hline Przewodność cieplna & \multicolumn{2}{|c|}{$\lambda[\mathrm{W} / \mathrm{m} \cdot \mathrm{K}]$} & 38 & \multicolumn{2}{|c|}{80} \\
\hline Ciepło właściwe & \multicolumn{2}{|c|}{$C_{p}[\mathrm{~J} / \mathrm{kg} \cdot \mathrm{K}]$} & 358 & \multicolumn{2}{|c|}{203} \\
\hline Współczynnik tarcia & \multicolumn{2}{|c|}{$\mu[-]$} & \multicolumn{3}{|l|}{0,3} \\
\hline
\end{tabular}

Zachowanie pary wiór-przedmiot obrabiany w warunkach tarcia opisano za pomocą zmodyfikowanego modelu Coulomba [1]. Model uwzględnia nieliniową wartość naprężenia stycznego $\tau$ wzdłuż powierzchni styku pary materiałów w zależności od współczynnika tarcia $\mu$ oraz naprężenia normalnego $\sigma_{n}$. Model jest wyrażony za pomocą zależności:

$$
\left\{\begin{aligned}
\tau=\mu \sigma_{n} & \text { dla } & \mu \sigma_{n}<\tau_{\max } \\
\tau=\tau_{\max } & \text { dla } & \mu \sigma_{n} \geq \tau_{\max }
\end{aligned}\right.
$$


Zależność wynikająca z tego modelu tarcia pozwala wyróżnić dwie strefy oddziaływania: strefę przylegania $\left(\mu \sigma_{n} \geq \tau_{\max }\right)$ oraz strefę poślizgu $\left(\mu \sigma_{n}<\tau_{\max }\right)$. W strefie przylegania określona jest wartość naprężenia stycznego odnosząca się do wartości stycznego naprężenia uplastyczniającego. Wartość tę wyznacza się w przybliżeniu na podstawie wartości granicy plastyczności $\sigma_{y} \mathrm{z}$ prostej zależności:

$$
\tau_{\max }=\tau_{y}=\frac{\sigma_{y}}{\sqrt{3}}
$$

Walidacji modeli numerycznych dokonano przez pomiar sił $F_{c}$ i $F_{f}$ w skrawaniu ortogonalnym tulei ze stali $42 \mathrm{CrMo} 4$ dla kolejnych stanów zużycia ostrza. Pasmo zużycia zostało zamodelowane na powierzchni przyłożenia płytek skrawających przez ich przeszlifowanie. Łącznie w badaniach analizowano cztery stany zużycia $V B_{B}$ : $0 ; 0,15 ; 0,28$ oraz $0,42 \mathrm{~mm}$ dla warunków skrawania przedstawionych na rys. 1 . Schemat stanowiska do pomiaru składowych siły całkowitej przedstawiono na rys. 2 .

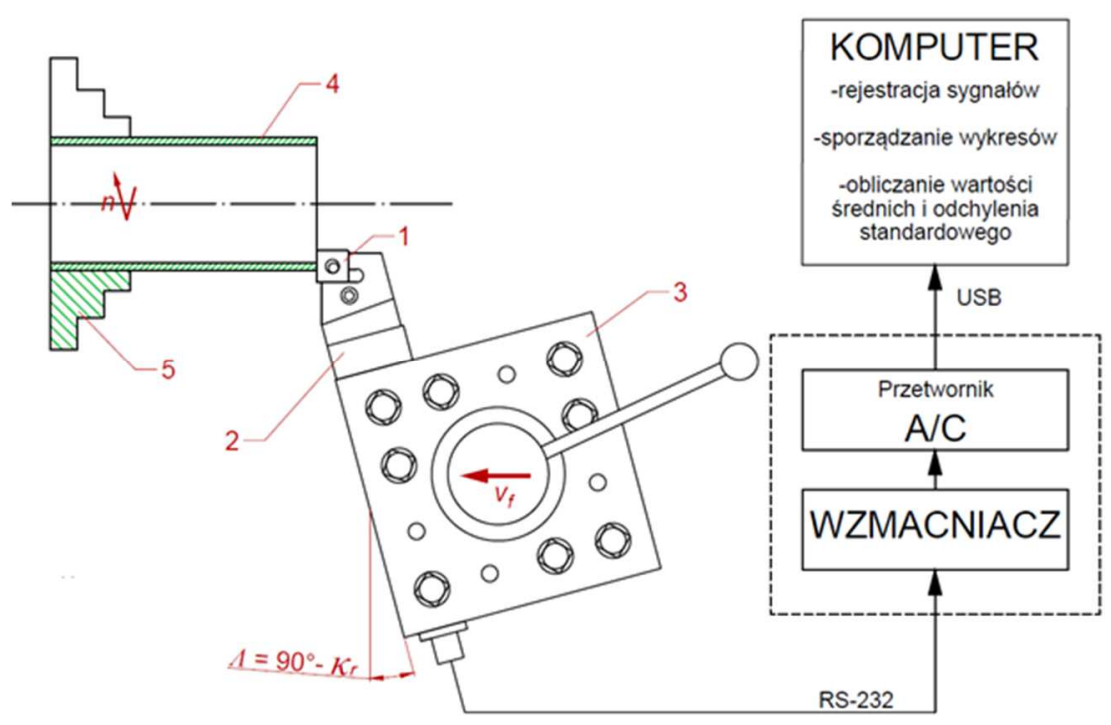

Rys. 2. Stanowisko do pomiaru sił skrawania w toczeniu ortogonalnym

Fig. 2. A stand for cutting force measurement in orthogonal turning

Płytka skrawająca (1) z określonym stanem zużycia jest zamocowana w dwuskładowym siłomierzu tensometrycznym (2). Warunki skrawania ortogonalnego zostały osiągnięte przez ustawienie krawędzi skrawającej płytki równolegle do czoła tulei (4), umieszczonej w uchwycie trójszczękowym (5) tokarki. Właściwe ustawienie krawędzi skrawającej zostało dokonane przez obrót imaka 
narzędziowego tokarki (3) o kąt równy $\Lambda=90^{\circ}-\kappa_{r}$. Sygnał z czujników tensometrycznych jest przekazywany do wzmacniacza, z którego następnie jest transformowany na postać cyfrową za pomocą przetwornika A/C. Cyfrowy sygnał jest rejestrowany w funkcji czasu przez oprogramowanie pomiarowe z zadaną częstością próbkowania. Dla dwóch zarejestrowanych sygnałów odpowiadających składowym $F_{c}$ i $F_{f}$ wybierano zakres stanu ustalonego, z którego program pomiarowy wyznaczał wartość średnią sił oraz odchylenie standardowe. Przykładowy przebieg zarejestrowanego sygnału pokazano na rys. 3. Dla każdego stanu zużycia dokonano po trzy pomiary z których każdy trwał około 3-5 sekund. Jako wynik zanotowano wartość średnią siły z trzech pomiarów.

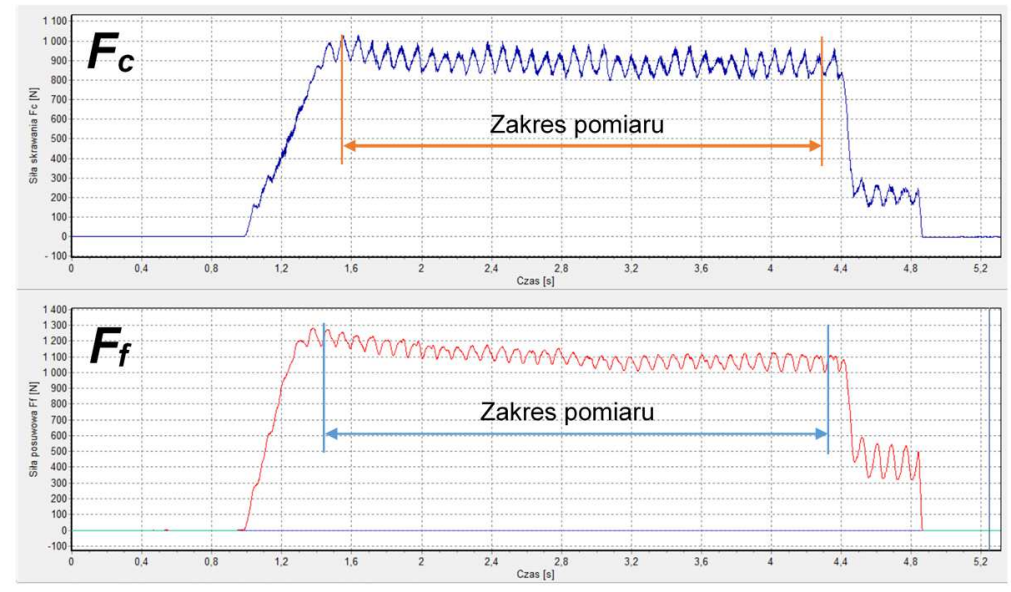

Rys. 3. Przykładowy pomiar sił dla toczenia ortogonalnego

Fig. 3. Exemplary measurement of forces in orthogonal turning

\section{Wyniki badań i analiza}

Ze względu na złożoność obliczeń dla symulacji z jawnym całkowaniem, wiążących duże zasoby obliczeniowe (czas, pamięć oraz liczba procesorów), podobnie jak w pracach $[4,6]$ ograniczono czas analizy do maksymalnie $1,2 \mathrm{~ms}$ procesu skrawania. Rysunek 4 przedstawia wartości siły skrawania i posuwowej w funkcji czasu dla symulacji dwóch wybranych przypadków zużycia. Wartość siły oscyluje wokół wartości ustalonej już po okresie $0,3 \mathrm{~ms}$ symulacji, który jest związany z początkowym zagłębieniem się klina w przedmiot obrabiany. Na rysunku 5a porównano składowe siły całkowitej $F_{c}$ i $F_{f}$ uzyskane z symulacji MES oraz z pomiarów podczas skrawania ortogonalnego dla różnych stanów zużycia ostrza. 

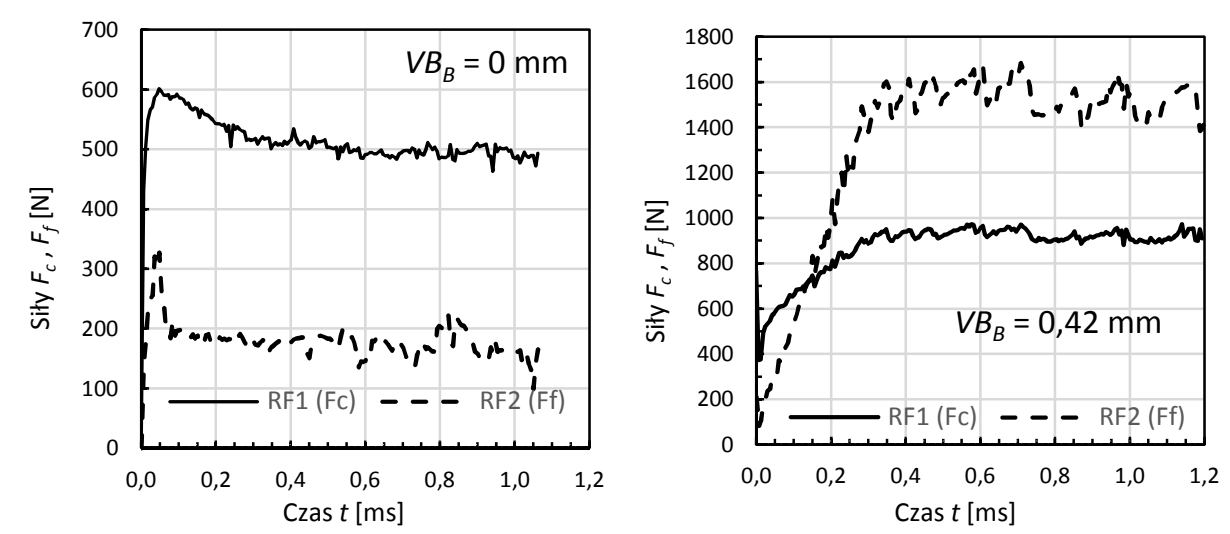

Rys. 4. Wartości siły obliczone w programie ABAQUS dla wskaźników $V B_{B}$

Fig. 4. Force values calculated in ABAQUS software for $V B_{B}$ index
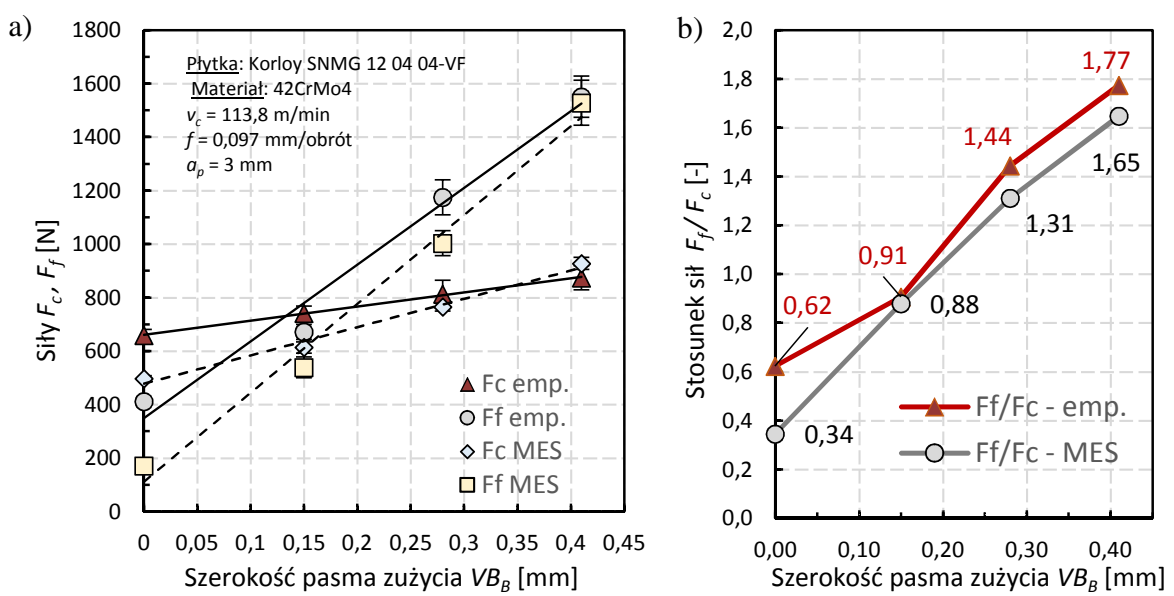

Rys. 5. Składowe siły całkowitej (a) oraz stosunek sił $F_{f} / F_{c}$ (b) w funkcji wskaźnika $V B_{B}$

Fig. 5. Components of total force (a) and $F_{f} / F_{c}$ forces ratio (b) as a function of $V B_{B}$ wear land

Wyniki pomiarów zamodelowano, wykorzystując do tego regresję potęgową, z czego pełne linie odnoszą się do pomiarów eksperymentalnych, a przerywane - do modeli numerycznych. Na podstawie badań można zauważyć, że modele numeryczne odwzorowują podstawową zależność towarzyszącą zużyciu ostrza, tj. wzrost składowych siły całkowitej. Zauważano jednak stosunkowo duże niedoszacowanie wartości sił dla $V B_{B}=0 \mathrm{~mm}$. Przyczyną tej rozbieżności dla wartości sił może być fakt, że stałe materiałowe wykorzystane w symulacjach pochodziły z literatury, gdzie badany materiał 42CrMo4 mógł się różnić w zakresie składu chemicznego, właściwości mechanicznych czy obróbki cieplnej. Na przestrzeni badanego pasma zużycia zauważalny jest znaczny przyrost wartości 
składowej posuwowej, a wraz ze wzrostem zużycia symulacje przewidują wartości sił z mniejszym błędem. Przyrost tej składowej jest znacznie bardziej dynamiczny niż składowej $F_{c}$. Oprócz walidacji za pomocą porównania wartości sił, modele zweryfikowano, porównując stosunek $F_{f} / F_{c}$ (rys. $5 \mathrm{~b}$ ). W analizie wpływu zużycia powierzchni przyłożenia na mechanikę procesu skrawania ortogonalnego odniesiono się do układu wektorów z rozszerzonego modelu Merchanta zaproponowane w pracach $[5,8]$, przedstawionego graficznie na rys. 6 a na tle węzłowych wartości zredukowanego naprężenia uzyskanych z MES.

W tradycyjnym modelu Merchanta dla nowego ostrza siła całkowita jest wyrażona jako wektor $R_{S}$ i przeciwny do niej wektor $R_{S}$ ', które razem utrzymują wiór w położeniu równowagi. Wektor $R_{S}$ może zostać rozłożony na składowe w kierunku siły skrawania $\left(F_{c S}\right)$ oraz w kierunku siły posuwowej $\left(F_{f S}\right)$. Wartości $F_{c S}$ oraz $F_{f S}$ odpowiadają kolejno sile skrawania i posuwowej dla obróbki nową płytką (dla $\left.V B_{B}=0\right)$. Wartości tych dwóch sił nie zostały wyznaczone analitycznie, lecz przez wykorzystanie modeli MES. Dodatkowo analiza MES umożliwia geometryczne znalezienie płaszczyzny ścinania przez śledzenie położenia punktów z najwyższymi wartościami naprężenia. Dzięki temu można rozłożyć wektor $R_{S}$ na składową siły ścinania $\left(F_{S}\right)$ działającą pod kątem ścinania $\Phi$ oraz siłę normalną $\left(F_{N}\right)$. W celu uwzględnienia wpływu zużycia na wielkości sił w procesie skrawania należy wprowadzić drugą parę sił: wektor $R_{w}$ oraz $R_{w}$ ', zdefiniowaną jako siła wpływu zużycia. Siłę $R_{w}$ można rozłożyć na dwie prostopadłe do siebie składowe: przyrostu siły skrawania $\left(F_{c w}\right)$ oraz w przyrostu siły posuwowej $\left(F_{f w}\right)$. Wartości tych składowych wyznacza się z zależności [5]:

$$
\begin{aligned}
& F_{c w}=F_{c}-F_{c S} \\
& F_{f w}=F_{f}-F_{f S}
\end{aligned}
$$

gdzie: $F_{c S}$ i $F_{f S}$ to kolejno składowa skrawania i posuwowa zmierzone dla skrawania nowym ostrzem. Schemat z rys. 6a obrazuje zauważoną już zależność, że zużycie ostrza na powierzchni przyłożenia powoduje znaczny przyrost składowej $F_{f}$, a mniejszy siły $F_{c}$.

Efekt ten jest widoczny na podstawie rozkładu nacisków działających na ostrze skrawające z rys. 6b-c, sporządzonych na podstawie węzłowych wartości nacisków ze zmiennej CPRESS w programie ABAQUS. Zmienna CPRESS została odczytana dla każdego kolejnego węzła na powierzchni ostrza i przedstawiona w postaci wykresu. Porównując rozkłady nacisków dla dwóch przypadków zużycia, spostrzega się, że pasmo starcia trze o przedmiot obrabiany, powodując powstanie znacznych nacisków, których dominująca składowa działa w kierunku posuwowym (pionowym). Skutkuje to przyrostem siły posuwowej $F_{f}$, przy czym wartość tego przyrostu będzie proporcjonalna do długości oddziaływania powierzchni przyłożenia z powierzchnią obrobioną, czyli długością pasma $V B_{B}$. 
a)

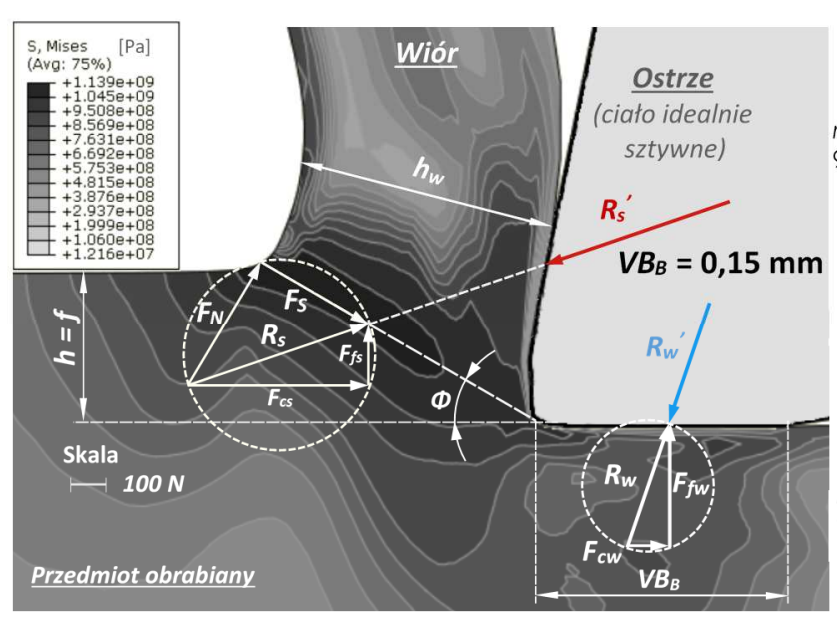

b)
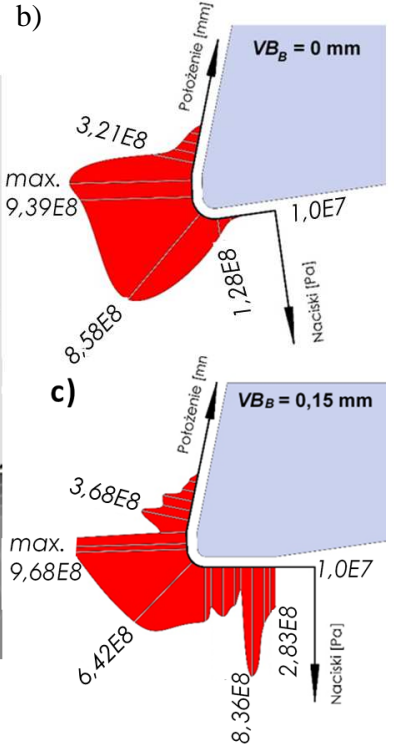

Rys. 6. Rozszerzony model sił w skrawaniu ortogonalnym uwzględniający wpływ zużycia (a), rozkład nacisków powierzchniowych dla nowego ostrza (b) oraz ostrza zużytego (c)

Fig. 6. An extended model of forces in orthogonal cutting including wear effect (a), distribution of contact pressure for new (b) and worn blade (c)

\section{Wnioski}

Postępujące zużycie ostrza na powierzchni przyłożenia powoduje monotoniczny wzrost składowych siły całkowitej. Model numeryczny potwierdza, że siła posuwowa jest bardziej wrażliwa na zużycie ostrza. Utwierdza to w przekonaniu, że sygnał siły posuwowej może być wykorzystywany do monitorowania stanu ostrza w skrawaniu ortogonalnym. Badania MES odwzorowały zjawisko tarcia ostrza o powierzchnię obrobioną, skutkującą znacznym przyrostem siły posuwowej. Kierunek towarzyszących tarciu nacisków powierzchniowych pokrywa się z kierunkiem siły $F_{f}$, dlatego długość starcia powierzchni przyłożenia będzie skutkować zwiększeniem kontaktu z przedmiotem obrabianym i proporcjonalnym zwiększeniem siły posuwowej. Potwierdzono zauważoną w pracach $[5,8]$ zależność, że rozszerzony model Merchanta pozwala uwzględnić wpływ zużycia na stan obciążenia ostrza. Model zakłada dwie przyczyny wpływające na obciążenie ostrza: składową związaną z mechanizmem ścinania $R_{S}$ oraz siłę spowodowaną zużyciem $R_{w}$.

\section{Literatura}

[1] Cai Y.J., Dou T., Duan C.Z., Li, Y.: Finite element simulation and experiment of chip formation process during high speed machining of AISI 1045 hardened steel, Int. J. Recent Trends Eng., 1 (2009) 123-130. 
[2] Docobu F., Arrazola P.J., Riviere-Lorphevre E., Filippi E.: Finite element prediction of the tool wear influence in Ti6Al4V machining, 15th CIRP Conf. Modelling of Machining Operations, Karlsruhe 2015.

[3] Kohir V., Dundur S.T.: Finite Element Simulation to study the effect of flank wear land inclination on cutting forces and temperature distribution in orthogonal machining, J. Eng. Fundamentals, 1 (2014) 30-42.

[4] Mashayekhi M., Salimi M., Vaziri M.R.: Evaluation of chip formation simulation models for material separation in the presence of damage models, Simulation Modelling Practice Theory, 19 (2011) 718-733.

[5] Milutinović M., Tanović L.: Cutting forces in hard turning comprising tool flank wear and its implication for the friction between tool and workpiece, Tehnicki vjesnik, 23 (2016) 1373-1380.

[6] Pantale O.: An ALE three-dimensional model of orthogonal and oblique metal cutting processes, Int. J. Forming Processes, 9 (1998) 371-388.

[7] Usui E., Kitagawwa T., Maekawa K., Shirakashi T.: Analytical prediction of flank wear of carbide tools in turning plain carbon steels, Bull. Japan Society Precision Eng., 23 (1989) 263-269.

[8] Wang J., Huang C.Z., Song W.G.: The effect of tool flank wear on the orthogonal cutting process and its practical implications, J. Mat. Proc. Technol., 142 (2003) 338-346.

\title{
FINITE ELEMENT METHOD ANALYSIS OF THE EFFECT OF TOOL FLANK WEAR ON TOOL LOADING IN ORTHOGONAL CUTTING OF 42CrMO4 STEEL
}

\begin{abstract}
S u m m a r y
In this paper an analysis of influence of flank wear $\left(V B_{B}\right.$ index) on total force components and pressure distribution in orthogonal cutting is presented. The experimental results were obtained based on the measurement of total force components using force gauge and values of reaction of the blade in the finite element model of the chip formation process. The experimental investigations were used in validation of the numerical models prepared in ABAQUS program. The determined range of wear has been modeled on the flank and their influence has been assessed by independent simulations. The numerical models of chip formation utilized Johnson-Cook equation to calculate the value and stress distribution in the workpiece. The blade with modeled wear was assumed as a rigid body. The mechanics of cutting process is presented based on the Merchant model of orthogonal cutting. The vectors of increments of total force components determined by FEM were geometrically drawn up to scale on cutting zone stress contour plot. The results indicated that increasing of wear described by $V B_{B}$ index has a direct effect on increasing of components of total force.
\end{abstract}

Keywords: finite element method, tool wear, modeling, pressure distribution, total force components

DOI: $10.7862 / \mathrm{rm} .2017 .46$

Przestano do redakcji: 21.08 .2017

Przyjęto do druku: 18.10.2017 
